\title{
The impact of corporate entrepreneurship on service innovation: A case of a South African banking institution
}

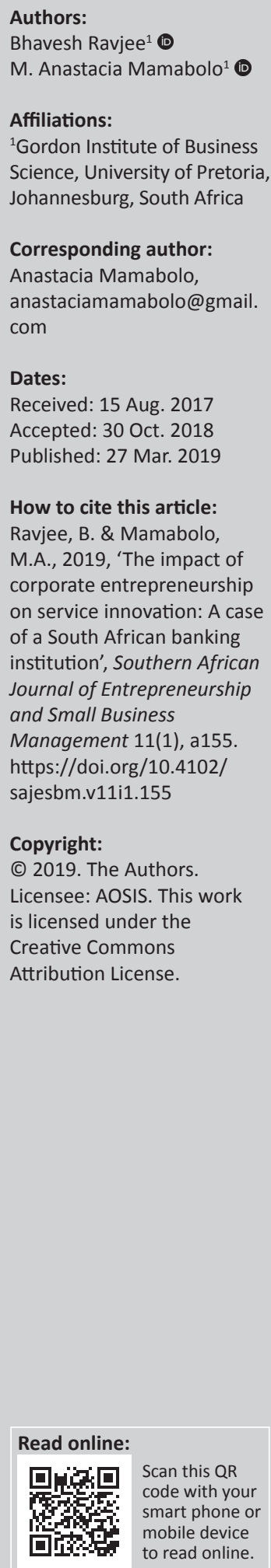

Background: Financial services companies pride themselves on delivering quality services to customers. To sustain their revenue streams in tough macroeconomic times and rapid technological growth, they are challenged to continuously innovate their services.

Aim: The purpose of this study was to determine the dimensions of corporate entrepreneurship (management support, work discretion, rewards and reinforcement, organisational boundaries and time availability) that predict service innovation in the financial services companies.

Setting: Business managers and analysts in a South African bank.

Methods: A case study approach was used to gather responses from business managers and analysts in one of the leading South African banks. The quantitative data were collected through an online survey utilising scales for corporate entrepreneurship and service innovation. Factor analysis and multiple linear regression were inferential statistical techniques used to analyse the data.

Results: The findings of the study illustrate that some dimensions of corporate entrepreneurship predicted service innovation. Rewards and recognition, management support and time availability significantly $(p<0.05)$ predicted service innovation. Work discretion and organisational boundaries were not significant predictors of service innovation. This may suggest that financial institutions limit employees' freedom to make decisions, use standardised procedures that may reduce employees' creativity to innovate and discourage employees from making mistakes.

Conclusion: The insights gained from this study are useful to companies that are looking for methods to revive or improve commercial services offered to customers and build competitive advantage through corporate entrepreneurship.

\section{Introduction}

Digital technology has the potential to radically change the operating environment of companies, thus challenging chief executive officers (CEOs) to revisit the assumption in their strategies (Grosskopf et al. 2015; Hirt \& Willmott 2014). Hirt and Willmott (2014) argued that digital technology has the potential to lower the barriers to entry, thus giving new rivals the opportunity to compete with larger corporations. Furthermore, they indicated that failure to adopt technologies that will improve the competitive advantage is to the detriment of the company. Yet, despite companies' awareness to respond to changes in the operating environment, some companies fail to align any combination of their strategy, culture or leadership (Hirt \& Willmott 2014) and are also slow to introduce proper strategies that would encourage innovation among employees (Kuratko \& Morris 2018).

In addition to the changes in digital technology, the aftermath of the 2008 global financial crisis presented a game changer for organisations, including financial companies (Kuratko, Hornsby \& Hayton 2015). Results from the PwC Banking Banana Skins 2015 survey reveal that economic and political factors continue to hinder the growth in this sector (Grosskopf et al. 2015). Given the multitude of external factors that have negatively affected the growth and competitive advantage of financial service companies, it becomes incumbent on CEOs to revisit their missions and analyse their operating environment, corporate strategy, employee skills and organisational culture and design (Grosskopf et al. 2015).

There is a consensus that these challenges can be addressed through innovation (Kuratko, Hornsby \& Covin 2014), and the introduction of corporate entrepreneurship within their organisations 
(Yunis, Tarhini \& Kassar 2018). Phan et al. (2009) narrated that corporate entrepreneurship is becoming popular in organisations that are not recognised as entrepreneurial, as a strategy to survive and succeed in increasingly competitive and financially constrained environments. In the same vein, this study determined the impact of corporate entrepreneurship on service innovation. Simply put, the study explored, if corporate entrepreneurship predicts service innovation. These two constructs, especially corporate entrepreneurship, have shown to improve the competitive advantage of companies (Corbett et al. 2013; Grawe, Chen \& Daugherty 2009; Hornsby et al. 2009; Kuratko et al. 2015) and organisational performance (Bierwerth, Schwens, Isidor \& Kabst 2015; Bloodgood et al. 2015). Accordingly, the realisation of the impact corporate entrepreneurship has on service innovation is important, given the difficult operating environment that has plagued financial services companies.

There is a plethora of corporate entrepreneurship definitions. The early scholars emphasised that corporate entrepreneurship has to do with product innovation, proactiveness and risktaking (Miller 1983; Morris \& Paul 1987). As the field was developing, Sharma and Chrisman (1999:18) clearly defined it as a 'process whereby an individual or group of individuals in an association with existing organisations create new organisation or instigate renewal or innovation within that organisation'. Other scholars explored the organisational factors or elements that can be used to measure corporate entrepreneurship (Hornsby, Kuratko \& Montagno 1999). They discovered several dimensions, namely, management support, work discretion, rewards and reinforcement, time availability and organisational boundaries. These dimensions have been developed into a research instrument known as a 'corporate entrepreneurship assessment instrument' (CEAI), which is increasingly used to measure corporate entrepreneurship (Hornsby et al. 1999; Kuratko et al. 2014; Steyn 2017). One of the important things about CEAI is that it can be used to assess the managers' support of corporate entrepreneurship (Hornsby et al. 2009). As this study aims to obtain the responses from the manager level, CEAI was considered an appropriate instrument.

Reflecting on innovation, research has shown that corporate entrepreneurship can be one of the ways to facilitate both product and service innovation in an organisation (Calisto \& Sarkar 2017; Goodale et al. 2011). However, studies in the information and communication technology industry, including finance, are yet to address corporate entrepreneurship in 'enhancing the impact of technological innovation on organisational performance' (Yunis et al. 2018:334). In addition, scholarly focus was more on product and process innovation, thus creating a gap regarding service innovation (Carlborg, Kindström \& Kowalkowski 2014). Service innovation can be seen as the creation of a service that is deemed new and beneficial to a certain individual or group of individuals (Barcet 2010; Flint et al. 2005; Grant 1991). It has the potential to create an impact at three different levels, namely, individual, organisational and societal (Chandler \& Vargo 2011). When considering the implementation or design of any service innovation, the impact to the customer should always be considered in conjunction with financial gain. However, behind successful service innovations are failures that provide valuable lessons (Shepherd, Covin \& Kuratko 2009; Witell et al. 2015).

The risks associated with service innovation have different meanings at each of these levels (Witell et al. 2015). From the individuals' point of view, risk encourages one not to adopt new services that easily. Companies are also reluctant to introduce innovation to services because of poor success rates. As a result, incremental innovations are chosen over radical ones to sustain a competitive advantage (Witell et al. 2015). However, this study suggests that corporate entrepreneurship would facilitate the adoption of service innovation.

The results of this study make four contributions. Firstly, it was seen that corporate entrepreneurship can be applied by financial companies to improve their innovation. These results will challenge other technology-based companies to create a conducive environment for corporate entrepreneurship to thrive. Secondly, the findings show that corporate entrepreneurship, especially rewards and recognition, management support and time availability, significantly predicts service innovation. The implication is that managers should support employees to be creative, afford them time to innovate and also increase the rewards and recognition given to employees. Thirdly, the nonsignificant findings of work discretion and organisational boundaries as predictors of service innovation suggest that context or the nature of the organisation should be considered in corporate entrepreneurship. In this instance, maybe the bureaucratic nature of financial institutions may discourage failure or mistakes, limit the employees' creativity to innovate and reduce their freedom to make their own decisions. Finally, insights gained from this study are useful to companies in other industries, for example, health care, that are yet to revive or improve commercial services offered to customers and build a competitive advantage through corporate entrepreneurship.

\section{Literature review Corporate entrepreneurship}

Corporate entrepreneurship is a well-defined field of study, which has been in existence for more than four decades (Bierwerth et al. 2015; Kuratko et al. 2015; Kuratko \& Morris 2018). Since its inception, it has gone through various stages, regarded by Kuratko and Audretsch (2013) as the 1980s, 1990s and 21st century, of defining what it is and strengthening its theoretical grounding. In the 1980s, corporate entrepreneurship was conceptualised as 'embodying entrepreneurial behaviour requiring organizational sanctions and resource commitments for the purpose of developing different types of value-creating innovations' (Kuratko \& Audretsch 2013:325). For instance, Miller (1983) focused on 
elements such as product innovation, proactiveness and risktaking which enable the organisations to pursue opportunities.

In the 1990s, corporate entrepreneurship was seen as two distinct, yet complementary features: corporate venturing and strategic renewal of the existing business (Guth \& Ginsberg 1990; Sharma \& Chrisman 1999). One of the popular definitions of corporate entrepreneurship is a:

... process, whereby an individual or group of individuals in an association with existing organisations create a new organisation or instigate renewal or innovation that can facilitate innovation within the company. (Sharma \& Chrisman 1999:18)

The main objective in the 1990s was to provide organisations with a competitive advantage and improved financial performance (Kuratko \& Audretsch 2013; Lumpkin \& Dess 1996; Zahra 1993).

During this era, the multidimensionality of corporate entrepreneurship - denoting renewal, innovation, risk-taking, proactiveness, corporate venturing - was a central argument. A quote from Covin and Miles (1999) says:

Corporate entrepreneurship is not just the old wine of organisational innovation in new bottles, as those who are cynical over the constant emergence of new managerial fads might suggest. Rather, corporate entrepreneurship refers to a distinct, multidimensional, and empirically verifiable set of organisational phenomena. (p. 50)

Recently, in the 21st century, focus changed to internal and external corporate entrepreneurship and the involvement of managers in corporate entrepreneurship (Hornsby et al. 2009; Hornsby, Kuratko \& Shaker 2002; Kuratko \& Audretsch 2013). The last addition is strategic entrepreneurship, which is focused on substantial innovation that will significantly improve the company's competitive advantage (Kuratko, Morris \& Covin 2011). Covin and Miles (1999) observed that innovation is the single common theme underlying all forms of corporate entrepreneurship. Table 1 is a brief summary of some of the key definitions and dimensions of corporate entrepreneurship.

Kuratko et al. (1990:49) encouraged scholars to 'continuously reassess the components or dimensions that predict or explain or shape the environment in which corporate entrepreneurship flourishes'. A review of the literature reveals the various dimensions or elements of corporate entrepreneurship that significantly contribute to developing a 'theoretically grounded understanding of corporate entrepreneurship that can be readily identified from the extant literature' (Kuratko et al. 2015:245). The dimensions, which form the CEAI, are management support, work discretion, rewards and reinforcement, time availability and organisation boundaries (Hornsby et al. 1999; Kuratko et al. 1990, 2014). This instrument is effective in measuring the managers' approach to corporate entrepreneurship (Hornsby et al. 2009).

In the case of management support, management needs to play the role of a facilitator. It is further argued by Demirci (2013) that senior and middle management are responsible for creating a suitable environment for corporate entrepreneurship. Work discretion - delegation of authority - when afforded to employees, provides them with the latitude to make decisions. This power influences employee attitudes and requires tolerance of failures from management. Time availability should also be considered as a resource to come up with innovative ideas and perform innovative activities. Flexibility of the organisational boundaries will enable information from the external environment to reach the internal environment of the organisation and facilitate innovative ideas (Hornsby et al. 2009; Kuratko et al. 2014; Miller, Fern \& Cardinal 2007). In 2017, a study conducted on a sample of 3180 respondents demonstrated that CEAI can be shorted to 20 measurement items and still maintain a good reliability score above 0.7 (Steyn 2017).

After reviewing the different approaches to corporate entrepreneurship (such as strategic renewal, corporate venturing, proactiveness, risk-taking, entrepreneurial

TABLE 1: Definitions and dimensions of corporate entrepreneurship.

\begin{tabular}{|c|c|c|}
\hline Authors & Definition & Dimensions \\
\hline $\begin{array}{l}\text { Miller (1983); Morris and } \\
\text { Paul (1987) }\end{array}$ & $\begin{array}{l}\text { It is explained as organisational renewal, innovation, constructive risk-taking, and the } \\
\text { conceptualisation and pursuit of new opportunities, a pursuit that often goes beyond } \\
\text { the efforts of one key manager. }\end{array}$ & Product innovation, proactiveness and risk-taking. \\
\hline $\begin{array}{l}\text { Guth and Ginsberg (1990); } \\
\text { Zahra (1993) }\end{array}$ & $\begin{array}{l}\text { Refers to (1) the birth of new businesses within existing organisations, that is, internal } \\
\text { innovation or venturing; and ( } 2 \text { ) the transformation of organisations through renewal } \\
\text { of the key ideas on which they are built, that is, strategic renewal. }\end{array}$ & $\begin{array}{l}\text { Innovation and strategic renewal of established } \\
\text { corporations. }\end{array}$ \\
\hline Sharma and Chrisman (1999) & $\begin{array}{l}\text { It is a process whereby an individual or a group of individuals, in association with an } \\
\text { existing organisation, create a new organisation or instigate renewal or innovation } \\
\text { within that organisation. }\end{array}$ & $\begin{array}{l}\text { The focus is on corporate venturing, innovation and } \\
\text { strategic renewal. }\end{array}$ \\
\hline Covin and Miles (1999) & $\begin{array}{l}\text { It relates to the organisation's ability to regularly introduce new products or enter } \\
\text { new markets, to the organisation per se, to the organisation's strategy for navigating } \\
\text { its current environment and to the organisation's creation and exploitation of new } \\
\text { product-market arenas, respectively. }\end{array}$ & $\begin{array}{l}\text { These forms will be labelled sustained regeneration, } \\
\text { organisational rejuvenation, strategic renewal and } \\
\text { domain redefinition. }\end{array}$ \\
\hline Lumpkin and Dess (1996) & $\begin{array}{l}\text { The presence of entrepreneurial orientation describes how a firm undertakes new } \\
\text { entry (in new or existing markets with new or existing products). }\end{array}$ & $\begin{array}{l}\text { Identified autonomy, innovativeness, risk-taking, } \\
\text { proactiveness and competitive aggressiveness. }\end{array}$ \\
\hline $\begin{array}{l}\text { Hornsby et al. (1999, 2002); } \\
\text { Kuratko et al. (2014); Kuratko, } \\
\text { Montagno and Hornsby (1990) }\end{array}$ & $\begin{array}{l}\text { Broadly defined as broad sense to include the development and implementation of } \\
\text { new ideas into the organisation (Hornsby et al. 2002). }\end{array}$ & $\begin{array}{l}\text { Management support for corporate entrepreneurship, } \\
\text { reward and resource availability, organisational } \\
\text { structure and boundaries, and time availability. }\end{array}$ \\
\hline $\begin{array}{l}\text { Kuratko and Audretsch (2013); } \\
\text { Kuratko et al. (2011) }\end{array}$ & $\begin{array}{l}\text { It is presented as a process whereby managers' entrepreneurial behaviour is critical } \\
\text { regardless of the primary reason (either corporate venturing or strategic } \\
\text { entrepreneurship) it is being pursued. }\end{array}$ & Corporate venturing and strategic entrepreneurship. \\
\hline
\end{tabular}

Note: Please see the full reference list of this article, Ravjee, B. \& Mamabolo, M.A., 2019, 'The impact of corporate entrepreneurship on service innovation: A case of a South African banking institution', Southern African Journal of Entrepreneurship and Small Business Management 11(1), a155. https://doi.org/10.4102/sajesbm.v11i1.155, for more information. 
orientation, strategic entrepreneurship), this study used CEAI to measure corporate entrepreneurship in a financial institution and how it predicts service innovation. The main reason for this choice was to examine how managers support entrepreneurial activities within their organisations (Hornsby et al. 2002, 2009; Kuratko et al. 2014).

\section{Service innovation}

'Today, continuous innovation - in terms of products, processes, and administrative routines and structures - is needed to compete effectively in the global markets of the 21st century.' (Kuratko et al. 2014:37)

The quote by Kuratko et al. (2014) emphasises the significance of innovation including that of services in today's business world. Services rendered are not thought of in terms of delivering a tangible product, which makes it somewhat difficult to measure and define. Service can be defined as an output of the interaction between service providers, consumers and technical characteristics (Morrar 2014). The definition of services by Morrar (2014) comprises four attributes, which include intangibility (products or processes that are not tangible), heterogeneity (non-uniformity in the end result), inseparability (consumers cannot be separated from the service experience) and perishability (services cannot be stored or exchanged and are thus transitory). Similarly, Katzan (2015:5) mentioned four dimensions to service innovation, which comprise 'the service concept, the client interface, the service delivery system, and technology options'. In this study, service innovation is defined as the creation of a new service to the benefit of the customers, and to increase the competitive advantage of the company (Barcet 2010; Grant 1991).

Legrand and Ljoiem (2013) argued that one of the core differences between the types of innovation, when contrasted with service innovation, is that service innovation has a strong focus on the customer. Morrar (2014) argued that through customers' feedback, an information loop is created that allows incremental innovation and new services to be offered. This shows that innovation in services is not solely reliant on technological research and development, but instead relies on human capital to add dimensions of strategy and competitiveness (Morrar 2014). Therefore, the accumulated knowledge of customers is also a source of bringing about innovation in services.

Although service innovation research has attracted scholars from different disciplines, there is a growing need to refine and promote the service research agenda (Ostrom et al. 2015; Wang et al. 2015) and incorporate corporate entrepreneurship (Calisto \& Sarkar 2017). One of the arguments is that service innovation has been discussed from a conceptual perspective, and has received less empirical research (Wang et al. 2015). Moreover, research focused on product and process innovation, consequently ignoring service innovation and its potential to contribute to the existing knowledge (Calisto \& Sarkar 2017; Carlborg et al. 2014). The reason given for this neglect is that service is perceived to consist of activities with low innovative frequency (Carlborg et al. 2014). Filling this gap, this study makes a contribution by combining the field of entrepreneurship with service innovation in a technologydriven industry (Yunis et al. 2018).

\section{Corporate entrepreneurship and service innovation}

A recent meta-analytic study demonstrated that corporate entrepreneurship is associated with organisational performance, both financial and nonfinancial (Bierwerth et al. 2015). On one hand, several studies found a positive relationship between corporate entrepreneurship and financial indicators. To name a few, financial indicators include return on sales and growth in sales (Zahra 1993); return on assets and return on sales (Zahra \& Covin 1995); sales growth, market share and profitability (Lumpkin \& Dess 1996) and market performance (Jancenelle, Storrud-Barnes \& Javalgi 2017). On the other hand, corporate entrepreneurship has been positively associated with nonfinancial measures such as organisations' performance relative to their competitors (Yunis et al. 2018) and product innovation (Chen et al. 2015). In addition to nonfinancial measures, this study uses service innovation as a measure of organisational performance, which is hypothesised to be predicted by corporate entrepreneurship. Figure 1 shows the dimensions of corporate entrepreneurship which may predict service innovation.

\section{Management support and service innovation}

Management support relates to the willingness of managers to facilitate entrepreneurial activities (Hornsby et al. 1999, 2009). For corporate entrepreneurship to thrive, the climate must be created by top-level management, employees must be trained and encouraged to innovate and finally, there must be innovation processes that move ideas from intent to reality (Seshadri \& Tripathy 2006). Management support is critical in enabling entrepreneurial activity to transition its efforts into innovation (Bloodgood et al. 2015; Hornsby et al. 2009; Lekmat \& Chelliah 2014). The levels of management are not only limited to senior levels, but also to middle- and lowlevel management (Hornsby et al. 2002). Senior management provides direction to implement corporate entrepreneurship initiatives at a macro-level, focusing on strategic imperatives. Middle-level managers play a critical role of strategically positioning the value of the corporate entrepreneurship

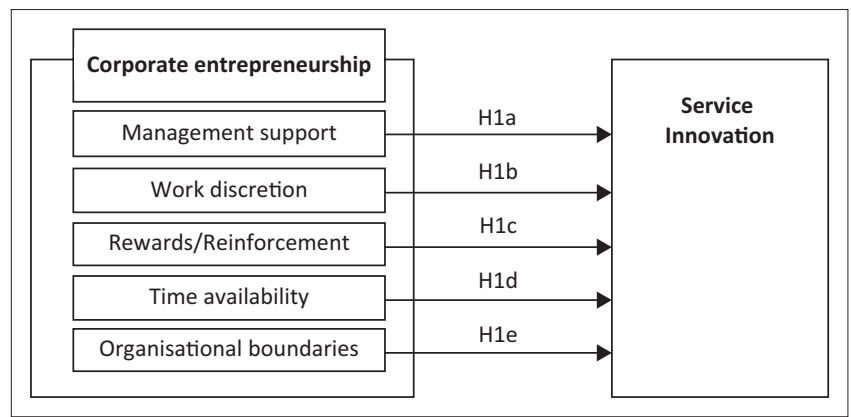

FIGURE 1: Conceptual model. 
initiatives for implementation by first-level managers, endorsing the initiatives and providing sufficient resources. Kuratko and Audretsch (2013:327) emphasised that 'through the shepherding function, middle-level managers champion, protect, nurture, and guide the entrepreneurial initiative'.

Although entrepreneurial initiatives are dependent on various levels of management to fulfil their responsibilities, managers must portray optimistic behaviour towards the initiative. Failure to do so is likely to lead to the demise of the initiative altogether. The coordinated efforts of managers across various levels are needed to convert entrepreneurial initiatives into competitive advantages for the organisation (Kuratko \& Audretsch 2013). Finally, Kuratko et al. (2014) mentioned that management support has a positive relationship with the organisational innovation. Hence, this study hypothesises that:

H1a: Management support afforded to employees significantly predicts service innovation.

\section{Work discretion and service innovation}

Organisations that adopt an independent ethical climate enable management to entrust employees with freedom and responsibility in making decisions (Manroop 2015) and acceptance of failure (Kuratko et al. 2014). This discretionary culture serves as a breeding ground for innovation and is suitable to organisations that are keen to delve into new ventures (Manroop 2015). Rigtering and Weitzel (2013) argued that for corporate entrepreneurship to be successful, employees need to establish the right levels of adequate trust between themselves and their direct managers. Once trust is established between the employee and their direct manager, the formalisation within the organisation does not serve as a hindrance. This two-way trust relationship in a formal organisation setting allows employees to get on with their behaviours of ideation, experimentation and implementation, thus leading to innovation (Hornsby et al. 2009; Kuratko et al. 2014; Rigtering \& Weitzel 2013). On this note, the hypothesis is that:

H1b: Work discretion afforded to employees significantly predicts service innovation.

\section{Rewards and reinforcement, and service innovation}

Giannikis and Nikandrou (2013) explained that human resource management who practise high-performance work systems have shown to positively influence a culture of corporate entrepreneurship within their organisations. Human resource practices that include rewards and compensation have also shown to provide an organisation with an advantage over competitors by encouraging creativity and innovation (Giannikis \& Nikandrou 2013). Furthermore, Kuratko et al. (2014) argued that reward systems encourage employees to take risks and be entrepreneurial. In short, rewarding and recognising employees is also significant to corporate entrepreneurship, as employees would naturally be motivated to participate through incentives (Lekmat \& Chelliah 2014). This will provide a network of interactive connections that enable entrepreneurial behaviour to self-create within an organisation, which will then serve as a source for new opportunities (Sørensen \& Fassiotto 2011). The benefits and incentives offered by such organisations provide the means to sustain and promote entrepreneurial behaviour and innovation among its employees, therefore:

H1c: A rewards and reinforcement culture significantly predicts service innovation.

\section{Time availability and service innovation}

Hornsby et al. (1999) emphasised that employees should perceive the availability of resources for entrepreneurial activities. One of the resources is time, which must be afforded to employees for entrepreneurial activities as part of their work schedule (Kuratko et al. 2014). Bloodgood et al. (2015) introduced a system dynamics view of corporate entrepreneurship, which sees the focus point as the opportunity. The stages in the system dynamics model comprise opportunity recognition, opportunity assessment, opportunity legitimation and, if successful, opportunity implementation. The stage-gate process sees innovations that arise from opportunities.

Opportunities are evaluated at various stages and through various gates in the process. Those that are not successful are not discarded, but analysed for reasons as to why the advancement to the next level was not attained. The learning obtained through this analysis is used to generate further entrepreneurial insights (Bloodgood et al. 2015), and plays an important role when operating in dynamic environments. Simply, the system dynamics perspective can be seen as a mechanism that reinforces entrepreneurial practices within the organisation. In short, employees need to be afforded time to generate ideas and take advantage of opportunities at different stages.

H1d: Time availability afforded to employees significantly predicts service innovation.

\section{Organisational boundaries and service innovation}

Organisational boundaries assess the extent to which information flows between the external environment and internal environment of the organisation (Kuratko et al. 2014). In addition, the focus is on the extent to which information or knowledge flows within the organisation to stimulate discourse that promotes entrepreneurial activity (Kuratko et al. 2014). The knowledge gained from corporate entrepreneurship initiatives enables organisations to enter into new markets. These initiatives span across formal and informal initiatives, which serve as sources to generate new knowledge and translate existing knowledge so that it can be applied practically. The generation of knowledge is achieved through pockets of work that permeate the organisation, known as entrepreneurial hubs (Zahra 2015). Miller et al. (2007) highlighted that flexible boundaries that promote the flow of information promote innovation.

H1e: Flexible organisational boundaries significantly predict service innovation. 


\section{Research design and methodology}

The research question answered in this study was: What is the relationship between corporate entrepreneurship and service innovation in financial service companies?

The main research objectives were to:

- determine the impact of corporate entrepreneurship on service innovation

- where corporate entrepreneurship is represented by management support, work discretion, rewards and reinforcement, time availability and organisational boundaries.

\section{Research design}

The study adopted a deductive approach and made use of existing literature on corporate entrepreneurship and service innovation to better understand the phenomenon studied. The initial strategy was to target a sample of South African companies in the financial services industry, predominantly companies that were classified as diversified banks. The intention was to target such companies because of the wide spectrum of business services that align fairly accurately with the objective of the study. Because of the lack of interest by companies to participate in this study, a case study strategy was chosen by focusing on a single organisation to gain the necessary findings and insights in line with the research objectives. The organisation that was selected had met the criteria of being classified as a diversified bank and was willing to allow its employees to participate in the survey. Eventually, the sampling unit or unit of analysis for this study was a financial services company in the form of a bank.

\section{Data gathering process}

Quantitative data were collected using an online survey, which contained questionnaires that represented scales for corporate entrepreneurship and service innovation. The scale for CEAI, was adopted from Kuratko et al. (2014), while the scale that measured service innovation was adopted from Grawe et al. (2009). CEAI had five dimensions, namely, management support, work discretion, rewards and reinforcement, time availability and organisational boundaries. Each of these CEAI dimensions and service innovation was measured through a set of measurement items, which utilised a Likert scale with five ordinal choices. The responses ranged from 1 = strongly disagree, 2 = disagree, $3=$ neutral, $4=$ agree and $5=$ strongly agree.

Upon receipt of formal consent from the authority within the organisation, the website link to the online survey was distributed via email to employees. Respondents who were invited to participate included process engineers, business analysts, software test analysts, as well as managers from junior to middle and senior management. The content of the email explicitly stated that the details of the company will be kept anonymous, and the findings will be reported and stored without identifiers. The first email was distributed via email on 15 August 2016, signalling the commencement of the data gathering process. Subsequent to this email, a reminder email was distributed on the 1 September 2016 as a gentle reminder to respondents. The reminder email also conveyed gratitude to those who had responded since the initial email. The official data gathering process concluded on 6 September 2016.

\section{Data analysis}

Before data analysis could begin, the data were prepared by dealing with the missing values, correcting the skewness of the data, re-coding reversed measurement items and testing the data distribution. Next, simple descriptive statistics were computed to provide an overview of the data. Moving to inferential statistics, the reliability and validity of the scales adopted were tested. These tests conducted comprised an iterative process of factor analysis, eliminating weak variables or items, with the aim of mathematically depicting dimensions (Hair et al. 2010). A reliability test was conducted using Cronbach's alpha coefficient, which further strengthened the dimensions derived from the factor analysis (Kline 2011). After computing the factor scores, a simple correlation test between the corporate entrepreneurship dimensions and service innovation was executed. Finally, a multiple regression model, comprising all dimensions of corporate entrepreneurship (independent variables) and service innovation (dependent variable), was run.

\section{Ethical consideration}

Ethical clearance has been approved (Protocol number: Temp2016-01538).

\section{Results \\ Descriptive statistics}

There were 97 responses gathered from the data. Their designations are as follows: business analysts (41\%), process engineers $(24 \%)$, management $(28 \%)$ and other $(7 \%)$. The 'other' category includes technical consultants, administration officer, business transformation leader, communications specialist and business coaches. The categories of work experience showed that participants had work experience ranging from 0 to 5 years (33\%), 6 to 10 years (32\%), 11 to 15 years $(21 \%), 16$ to 20 years $(9 \%)$ and $5 \%$ of more than 20 years. Their management levels consisted of nonmanagerial (e.g. specialist role) $(47 \%)$, junior management (e.g. team leader or senior specialist role) $(16 \%)$, middle management (e.g. head of business function) (18\%), senior management (e.g. general manager) (13\%) and executive management (6\%). The data show that over $53 \%$ of the respondents were in managerial positions.

The reliability of the research instrument was tested before the main analysis and the results showed that all dimensions had Cronbach's alpha values above 0.70, indicating that the scale had internal consistency and measured what was 
intended (Kline 2011). The findings showed management support with $\alpha=0.904$, work discretion with $\alpha=0.808$, rewards and reinforcement with $\alpha=0.827$, time availability with $\alpha=0.718$, organisational behaviour with $\alpha=0.732$ and service innovation with $\alpha=0.901$.

\section{Factor analysis}

Hair et al. (2010) indicated that the factor analysis is designed to define the underlying structure among the variables in the analysis. Factor analysis was executed over nine iterations to arrive at the set of nine factors or components. Although the factors comprised a single variable, the items were removed in preparation for the next iteration of the factor analysis. The Kaiser-Meyer-Olkin measure and Bartlett's test of sphericity were observed through each iteration of the factor analysis to assess, if the data were fit for factor analysis (Hair et al. 2010). Furthermore, the scree plot graphs produced were observed for the point of inflection. Any items with absolute value below 0.50 were omitted from the factor analysis. After the ninth iteration, there were 9 factors with 39 items, Kaiser-Meyer-Olkin value of 0.796 and Bartlett's test of sphericity with $p=0.00$.

The rotated factor matrix shown in Table 2 illustrates the factor loading after the ninth iteration of the factor analysis.

Table 2 depicts the variables that were grouped together. If a variable was associated across more than one factor, the highest factor loading took precedence. Post-factor analysis, the following items in Table 3 were grouped to form the new factors or components. Their reliability scores were above the recommended 0.7 (Kline 2011)

Table 3 shows that all five independent variables were retained. Although the variables were retained, some of the

TABLE 2: Rotated factor matrix.

\begin{tabular}{|c|c|c|c|c|c|c|c|c|c|}
\hline \multirow[t]{2}{*}{ Items labels } & \multicolumn{9}{|c|}{ Component } \\
\hline & 1 & 2 & 3 & 4 & 5 & 6 & 7 & 8 & 9 \\
\hline SI_05 & 0.788 & - & - & - & - & - & - & - & - \\
\hline CE_MS_2 & 0.752 & - & - & - & - & - & - & - & - \\
\hline SI_04 & 0.732 & - & - & - & - & - & - & - & - \\
\hline CE_MS_1 & 0.727 & - & - & - & - & - & - & - & - \\
\hline SI_01 & 0.714 & - & - & - & - & - & - & - & - \\
\hline SI_03 & 0.657 & - & - & - & - & - & - & - & - \\
\hline SI_02 & 0.651 & - & - & - & - & - & - & - & - \\
\hline CE_WD_27 & - & 0.789 & - & - & - & - & - & - & - \\
\hline CE_WD_28 & - & 0.767 & - & - & - & - & - & - & - \\
\hline CE_WD_26 & - & 0.747 & - & - & - & - & - & - & - \\
\hline CE_WD_25 & - & 0.655 & - & - & - & - & - & - & - \\
\hline CE_WD_29 & - & 0.599 & - & - & - & - & - & - & - \\
\hline CE_WD_24 & - & 0.576 & - & - & - & - & - & - & - \\
\hline CE_WD_23 & - & 0.548 & - & - & - & - & - & - & - \\
\hline CE_MS_13 & - & - & 0.812 & - & - & - & - & - & - \\
\hline CE_MS_15 & - & - & 0.727 & - & - & - & - & - & - \\
\hline CE_MS_14 & - & - & 0.725 & - & - & - & - & - & - \\
\hline CE_MS_12 & - & - & 0.681 & - & - & - & - & - & - \\
\hline CE_MS_3 & - & - & 0.589 & - & - & - & - & - & - \\
\hline CE_MS_16 & - & - & 0.569 & - & - & - & - & - & - \\
\hline CE_MS_4 & - & - & 0.547 & - & - & - & - & - & - \\
\hline CE_RR_32 & - & - & - & 0.794 & - & - & - & - & - \\
\hline CE_RR_35 & - & - & - & 0.746 & - & - & - & - & - \\
\hline CE_RR_33 & - & - & - & 0.686 & - & - & - & - & - \\
\hline CE_RR_34 & - & - & - & 0.619 & - & - & - & - & - \\
\hline CE_OB_47 & - & - & - & - & 0.702 & - & - & - & - \\
\hline CE_OB_46 & - & - & - & - & 0.691 & - & - & - & - \\
\hline CE_TA_38 & - & - & - & - & - & 0.851 & - & - & - \\
\hline CE_TA_37 & - & - & - & - & - & 0.783 & - & - & - \\
\hline CE_TA_41 & - & - & - & - & - & 0.523 & - & - & - \\
\hline CE_OB_42 & - & - & - & - & - & - & 0.745 & - & - \\
\hline CE_OB_43 & - & - & - & - & - & - & 0.713 & - & - \\
\hline CE_TA_39 & - & - & - & - & - & - & - & 0.830 & - \\
\hline CE_TA_40 & - & - & - & - & - & - & - & 0.709 & - \\
\hline CE_MS_10 & - & - & - & - & - & - & - & - & 0.752 \\
\hline CE_MS_17 & - & - & - & - & - & - & - & - & 0.603 \\
\hline
\end{tabular}

Note: Extraction method: principal component analysis; rotation method: varimax with Kaiser normalisation. Rotation converged in nine iterations. 
measurement items from the original scale were omitted as a result of the factor analysis. The dependent variable, service innovation, retained all items from the service innovation scale adopted from Grawe et al. (2009). In addition to this, two other items were added from management support, which are 'my organisation is quick to use improved methods that are developed by workers' and 'my organisation is quick to use improved work methods'.

\section{Correlation}

Table 4 depicts the Pearson correlation coefficients for each of the corporate entrepreneurship dimensions against the service innovation scale.

The summary of the correlation findings reveals that management support $(r=0.687)$ has its strongest significant association with service innovation, followed by work discretion $(r=0.550)$, rewards and recognition $(r=0.585)$ and time availability $(r=0.355)$, respectively. Organisational boundaries were negatively correlated with service innovation, suggesting that more rigid organisational boundaries may result in decreased service innovation. This finding will be confirmed by multiple linear regression presented in the next section.

\section{Multiple linear regression}

All dimensions of corporate entrepreneurship that represent the independent variable were computed together in multiple regression analysis to predict service innovation. The model summary and coefficients computed are depicted in Table 5.

The multiple correlation coefficient $R$ was 0.773 , supporting the notion that the independent variables comprising corporate entrepreneurship as a collective are good predictors of dependent variable service innovation. The $R^{2}$ was computed as 0.597 with the adjusted $R^{2}$ computed as 0.575 . The $R^{2}$ value explained the variance in the dependent variable that was attributable by the independent variables. Therefore, it can be said that $59.7 \%$ of the variance in service innovation was attributable to corporate entrepreneurship (see Table 5).

Results from the analysis of variance (ANOVA) test displayed in Table 6 showed that the proposed model was a good fit for the data with $p=0.000$.

The equation to the model was derived using the B (beta) column under the unstandardised coefficients shown in Table 7.

The coefficients shown in Table 7 demonstrate that when all variables were computed together in multiple regression, rewards and recognition (sig. $=0.00)$, management support (sig. $=0.000)$ and time availability (sig. $=0.044)$ were significant predictors of service innovation. Organisational boundaries (sig. $=0.418)$ and work discretion (sig. $=0.786)$ were found to be insignificant predictors of service innovation.

The model equation can be written as: Service innovation = $0.055+0.642$ (management support) +0.425 (rewards and reinforcement) +0.180 (time availability)

TABLE 6: Analysis of variance of corporate entrepreneurship and service innovation: Analysis of variance. $\dagger$

\begin{tabular}{llccccc}
\hline Model & Test & Sum of squares & $\boldsymbol{d f}$ & Mean square & $\boldsymbol{F}$ value & Sig. \\
\hline 1 & Regression & 1.471 & 5 & 0.294 & 26.966 & $0.000 \%$ \\
& Residual & 0.993 & 91 & 0.011 & - & - \\
& Total & 2.465 & 96 & - & - & - \\
\hline
\end{tabular}

$d f$, degree of freedom; F, Fisher; Sig., significant.

$\dagger$ Dependent variable: service innovation; \$Predictors: (Constant), management support, work discretion, rewards and reinforcement, time availability and organisational boundaries.

TABLE 3: Final factor definition.

\begin{tabular}{llcl}
\hline Factor & Factor name & Items & Items labels \\
\hline 1 & Service innovation & 7 & CE_MS_1; CE_MS_2; SI_01; SI_02; SI_03; SI_04; SI_05 \\
2 & Work discretion & 8 & CE_WD_22; CE_WD_23; CE_WD_24; CE_WD_25; CE_WD_26; CE_WD_27; CE_WD_28; CE_WD_29 \\
3 & Management support & 7 & CE_MS_3; CE_MS_4; CE_MS_12; CE_MS_13; CE_MS_14; CE_MS_15; CE_MS_16 \\
4 & Rewards and reinforcement & 4 & CE_RR_32; CE_RR_33; CE_RR_34; CE_RR_35 \\
5 & Organisational boundaries & 4 & CE_OB_47; CE_OB_46; CE_OB_48; CE_OB_44 \\
6 & Time availability & 3 & CE_TA_37; CE_TA_38; CE_TA_41 \\
\hline
\end{tabular}

TABLE 4: Pearson's correlation coefficient.

\begin{tabular}{llllll}
\hline Dependent variable & $\begin{array}{l}\text { Correlation } \\
\text { coefficient }\end{array}$ & $\begin{array}{l}\text { Work } \\
\text { discretion }\end{array}$ & $\begin{array}{l}\text { Management } \\
\text { support }\end{array}$ & $\begin{array}{l}\text { Rewards and } \\
\text { recognition }\end{array}$ & $\begin{array}{l}\text { Organisational } \\
\text { boundaries }\end{array}$ \\
\cline { 2 - 6 } Service innovation & Pearson correlation & 0.550 & 0.687 & 0.585 & $\begin{array}{l}\text { Time } \\
\text { availability }\end{array}$ \\
& Sig. (two-tailed) & 0.000 & 0.000 & 0.000 & 0.240 \\
& $N$ & 97 & 97 & 97 & 0.018 \\
& $N$ & 97 & 97 \\
\hline
\end{tabular}

TABLE 5: Multiple regression corporate entrepreneurship and service innovation: model summary. ${ }^{\text {a }}$

\begin{tabular}{|c|c|c|c|c|c|c|c|c|c|}
\hline \multirow[t]{2}{*}{ Model } & \multirow[t]{2}{*}{$R$} & \multirow[t]{2}{*}{$R^{2}$} & \multirow[t]{2}{*}{ Adjusted $R^{2}$} & \multirow{2}{*}{$\begin{array}{l}\text { Standard error of } \\
\text { the estimate }\end{array}$} & \multicolumn{5}{|c|}{ Change statistics } \\
\hline & & & & & $R^{2}$ change & $F$ change & $d f 1$ & $d f 2$ & Sig. $F$ change \\
\hline 1 & $0.773^{b}$ & 0.597 & 0.575 & 0.10447 & 0.597 & 26.966 & 5 & 91 & 0.000 \\
\hline
\end{tabular}

$d f$, degree of freedom; F, Fisher; $\mathrm{R}$, correlation; $\mathrm{R}^{2}$ coefficient of determination; Sig., significant.

aDependent variable: service innovation

bPredictors: (constant), management support, work discretion, rewards and reinforcement, time availability and organisational boundaries. 


\begin{tabular}{|c|c|c|c|c|c|c|c|c|c|c|c|}
\hline \multirow[t]{2}{*}{ Model } & \multirow[t]{2}{*}{ Independent variables } & \multicolumn{2}{|c|}{ Unstandardised coefficients } & \multirow{2}{*}{$\begin{array}{l}\text { Standardised } \\
\text { coefficients } \\
\text { (beta) }\end{array}$} & \multirow[t]{2}{*}{$t$} & \multirow[t]{2}{*}{ Significance } & \multicolumn{3}{|c|}{ Correlations } & \multicolumn{2}{|c|}{ Collinearity statistics } \\
\hline & & $B$ & Standard error & & & & Zero-order & Partial & $\begin{array}{l}\text { Part } \\
\end{array}$ & Tolerance & VIF \\
\hline \multirow[t]{5}{*}{1} & (Constant) & 0.055 & 0.085 & - & 0.652 & 0.516 & - & - & - & - & \\
\hline & Management support & 0.642 & 0.114 & 0.474 & 5.633 & 0.000 & 0.687 & 0.508 & 0.375 & 0.625 & 1.600 \\
\hline & Work discretion & 0.031 & 0.114 & 0.026 & 0.272 & 0.786 & 0.550 & 0.028 & 0.018 & 0.490 & 2.040 \\
\hline & Rewards and reinforcement & 0.425 & 0.111 & 0.320 & 3.837 & 0.000 & 0.585 & 0.373 & 0.255 & 0.635 & 1.574 \\
\hline & Time availability & 0.180 & 0.088 & 0.157 & 2.038 & 0.044 & 0.355 & 0.209 & 0.136 & 0.749 & 1.334 \\
\hline
\end{tabular}

$\dagger$, Dependent variable: service innovation

VIF, Variance Inflation Factor; $B$, beta.

TABLE 8: Results of hypotheses testing.

\begin{tabular}{ll}
\hline Hypotheses & Result \\
\hline $\begin{array}{l}\text { H1a: Management support to employee } \\
\text { significantly predicts service innovation }\end{array}$ & Supported, sig. $=0.00$ \\
$\begin{array}{l}\text { H1b: Work discretion afforded to employees } \\
\text { significantly predicts service innovation }\end{array}$ & Not supported, sig. $=0.786$ \\
$\begin{array}{l}\text { H1c: Rewards and reinforcement culture } \\
\text { significantly predicts service innovation }\end{array}$ & Supported, sig. $=0.00$ \\
$\begin{array}{l}\text { H1d: Time availability afforded to employees } \\
\text { significantly predicts service innovation }\end{array}$ & Supported, sig. $=0.044$ \\
$\begin{array}{l}\text { H1e: } \text { The flexible organisational boundaries } \\
\text { significantly predicts service innovation }\end{array}$ & Not supported, sig. $=0.418$ \\
\hline
\end{tabular}

significantly predicts service innovation

sig., significance.

\section{Summary of the results}

Through the application of factor analysis, all dimensions of CE were identified. However, they were reduced in size in terms of their associated measurement items. Based on the multiple linear regression results, the hypotheses are concluded, as shown in Table 8.

\section{Discussion}

The findings of the study suggest that some dimensions of corporate entrepreneurship predict service innovation especially through rewards and recognition, management support and time availability. These findings are synonymous with the recommendations provided by Watanabe, Fukuda and Nishimura (2015) on service innovation, who argued that sole reliance on management support is not ideal. In addition, Goodalea et al. (2011) also found that when the operational control attributes such as risk and process controls are considered, all the dimensions of corporate entrepreneurship were positively associated with innovation performance. Therefore, to successfully implement corporate entrepreneurship in an organisation, all the dimensions and operational control attributes contribute to service innovation must be taken into account.

H1a: Management support afforded to employees significantly predicts service innovation.

The findings of this study established evidence that management support in an entrepreneurial context influences service innovation in an organisation. This is consistent with the notion that the role of managers from the top level down to first level has specific functions that facilitate the implementation of entrepreneurial behaviour and improve the competitive advantage of the organisation (Bloodgood et al. 2015; Seshadri \& Tripathy 2006). Management, as a support function, creates a suitable environment for employees to adopt an entrepreneurial mind-set and conduct (Hornsby et al. 2009; Hornsby, Kuratko \& Shaker 2002). The result of entrepreneurial behaviour portrayed by management and employees creates a two-pronged approach to sustaining the entrepreneurial orientation of the organisation. Scholars refer to this as a top-down and bottom-up approach (Demirci 2013).

H1b: Work discretion afforded to employees significantly predicts service innovation.

The regression results showed that work discretion is not a significant predictor of service innovation $(p>0.05)$, which is contrary to the existing literature (Manroop 2015; Rigtering \& Weitzel 2013; Witell et al. 2015). The measurement items used suggest that where employees are not given the freedom to make decisions or judgements, there is little tolerance of failure and, instead, criticism for mistakes made on the job. Management is possibly minimising potential failure because mistakes on the job might be too costly.

The findings suggest a review on or a debate about the influence of context on corporate entrepreneurship. Zahra and Covin (1995) found that corporate entrepreneurship is active in companies that are operating in hostile environments. Scholars can debate context with regard to the industry, location, roles, institutions and many others.

H1c: A rewards and reinforcement culture significantly predicts service innovation.

The study confirmed that rewards and reinforcement positively influence service innovation and are a prerequisite to motivate employees to drive innovation in services. The findings are in line with the argument that employees need to be motivated through a form of reward and recognition to sustain corporate entrepreneurship within the organisation (Lekmat \& Chelliah 2014). Therefore, incentivising employees and recognising employee efforts are important to drive entrepreneurial behaviour. Also, the reinforcement of this behaviour is important through communication of corporate values and vision, allowing employees to create formal and informal networks, and access to opportunities that may not necessarily be obvious outside the operating environment; this creates the required motivation for employees to thrive. In sum, human resource systems play a significant role in facilitating and realising rewards and reinforcement.

H1d: Time availability afforded to employees significantly predicts service innovation. 
The fact that time availability positively influences service innovation is aligned with the existing literature. These findings showed that time availability also had a positive correlation to service innovation (Bloodgood et al. 2015; Kuratko et al. 2014). The financial institution in the study gave employees time to be innovative and entrepreneurial, which promotes an entrepreneurial culture (Bloodgood et al. 2015; Kuratko et al. 2014).

H1e: Flexible organisational boundaries significantly predict service innovation.

The results of the study demonstrated a non-significant association between flexible organisational boundaries and service innovation. These findings are contrary to Kuratko et al. (2014) who argued that flexible organisational boundaries play a significant role in the sharing of information which lead to innovation. The reason for this may be because of the notion that in the banking institutions there are standardised procedures, written rules and procedures of executing the tasks. As some of the participants were working in specialist roles, it could be possible that their roles do not have flexible boundaries. However, this does not answer the negative correlation with service innovation. It could be argued that service innovation can also take place within secure boundaries, within the regulated rules and procedures. A further assumption could be that relaxing the boundaries too much would make employees feel that they do not have the necessary information to perform their roles adequately or they become uncertain about what is expected of them (Yavas et al. 2003). An explanation for this finding can be invested in future research.

\section{Conclusion}

The findings from this case study, based on a financial institution in the South African market, support the notion that some dimensions of corporate entrepreneurship predict service innovation. Some of corporate entrepreneurship dimensions, specifically rewards and reinforcements, management support and time availability, were found to be positively correlated with service innovation. The results showed that management support is the strongest predictor of service innovation. Therefore, management needs to realise that leadership is needed to transform organisations and promote corporate entrepreneurship. For instance, if employees portray an entrepreneurial culture, managers, although not obliged, should be supportive of such employees without first having to receive the necessary support from upper management.

Not all dimensions were found to be positive. The findings showed that work discretion did not significantly predict service innovation, suggesting that employees may not be having freedom to be creative and make their own decisions. Furthermore, organisational boundaries were a non-significant predictor of service innovation, meaning that the banking institution may have more rigid, standardised procedures, which limit the employees' ability to be innovative. To promote entrepreneurship, managers need to be more flexible and allow staff the freedom to be creative, by relaxing some of the standardised procedures and rules. To scholars, these findings suggest the context in which the company operates or the nature of the company may limit its ability to fully explore corporate entrepreneurship.

\section{Limitations of the research}

The case study approach only provides a view from a single organisation, and thus is not representative for all companies in the financial services industry in South Africa. Moreover, with only 97 responses obtained from various levels in the organisation, this provided a limited sample size from which to draw inferential statistics that were representative of the entire organisation. Therefore, this study cannot be generalised to other banking institutions. However, it has provided great insights about using corporate entrepreneurship to improve the competitive advantage of the firm.

\section{Future research}

Although the service innovation scale in this study proved to be reliable, there are no scales to measure the extent to which services are innovated within an organisation. Based on service design practitioners' tool and techniques, service innovation scales can be enhanced through focus on innovation and by expanding the focus on the customer. Furthermore, at a high level, the scale could also be architected to focus on visible as well invisible aspects (Morrar 2014) to develop a service innovation framework.

Studies in financial service companies should also establish their portfolio of innovation to establish the extent to which emphasis is placed on production innovation compared to service innovation. Neither of these innovation types should be neglected; however, a fair balance needs to be maintained. In addition, congruence between these two innovation methods should be attained to personify efficacy of the overall innovation efforts, with the primary focus placed on the customer. Future research in this regard will contribute to the development of scales to measure these innovation types and the level of integration in efforts to achieve alignment.

A quantitative study, including several financial companies, will validate the results of this study, especially work discretion and organisational boundaries which were found to be non-significant predictors of service innovation. Future studies can use the context or the nature of the firm as a moderating variable between corporate entrepreneurship and service innovation or any organisational performance measure.

Finally, there is a need to focus on banking or technology capabilities that may facilitate corporate entrepreneurship, and which will consequently impact on organisational performance. These studies demonstrate how companies can 
improve their competitive advantage by taking cognisance of the factors working within the organisation.

\section{Acknowledgements Competing interests}

The authors declare that they have no financial or personal relationships that may have improperly impacted them in writing this article.

\section{Authors' contribution}

B.R. collected the data and wrote the first draft, while M.A.M. analysed the data and finalised the manuscript.

\section{References}

Barcet, A., 2010, 'Innovation in services: A new paradigm and innovation model', in F. Gallouj \& F. Djellal (eds.), The handbook of innovation and services: A multidisciplinary perspective, pp. 49-67, Edward Elgar, Cheltenham.

Bierwerth, M., Schwens, C., Isidor, R. \& Kabst, R., 2015, 'Corporate entrepreneurship and performance: A meta-analysis', Small Business Economics 45(2), 255-278. https://doi.org/10.1007/s11187-015-9629-1

Bloodgood, J.M., Hornsby, J.S., Burkemper, A.C. \& Sarooghi, H., 2015, 'A system dynamics perspective of corporate entrepreneurship', Small Business Economics 45(2), 383-402. https://doi.org/10.1007/s11187-015-9634-4

Calisto, M.L. \& Sarkar, S., 2017, 'Innovation and corporate entrepreneurship in service businesses', Service Business 11(3), 581-600. https://doi.org/10.1007/s11628016-0321-6

Carlborg, P., Kindström, D. \& Kowalkowski, C., 2014, 'The evolution of service innovation research: A critical review and synthesis', The Service Industries Journal 34(5), 373-398. https://doi.org/10.1080/02642069.2013.780044

Chandler, J.D. \& Vargo, S.L., 2011, 'Contextualization and value-in-context: How context frames exchange', Marketing Theory 11(1), 35-49. https://doi.org/ 10.1177/1470593110393713

Chen, Y., Wang, Y., Nevo, S., Benitez-Amado, J. \& Kou, G., 2015, 'IT capabilities and product innovation performance: The roles of corporate entrepreneurship and competitive intensity', Information \& Management 52(6), 643-657. https://doi. competitive intensity', Informa
org/10.1016/j.im.2015.05.003

Corbett, A. Covin, J.G., O'Connor, G.C. \& Tucci, C.L., 2013, 'Corporate entrepreneurship: State-of-the-art research and a future research agenda', Journal of Production Management 30(5), 812-820. https://doi.org/10.1111/jpim.12031

Covin, J.G. \& Miles, M.P., 1999, 'Corporate entrepreneurship and the pursuit of competitive advantage', Entrepreneurship Theory and Practice 23(3), 47-63. https://doi.org/10.1177/104225879902300304

Demirci, A.E., 2013, 'In pursuit of corporate entrepreneurship: How employees perceive the role of formalization and centralization', Journal of Management Research 5(3), 115-133. https://doi.org/10.5296/jmr.v5i3.3597

Flint, D.J., Larsson, E., Gammelgaard, B. \& Mentzer, J.T., 2005, 'Logistics innovation: A customer value-oriented social process', Journal of Business Logistics 26(1) 113-147. https://doi.org/10.1002/j.2158-1592.2005.tb00196.x

Giannikis, S. \& Nikandrou, I., 2013, 'The impact of corporate entrepreneurship and high performance work systems on employees job attitudes: Empirical evidence from Greece during the economic downturn', The International Journal of Human from Greece during the economic downturn', The International Journal of Human
Resource Management 24(19), 3644-3666. https://doi.org.uplib.idm.oclc.org/ Resource Management 24(19),
10.1080/09585192.2013.778316

Goodale, J.C., Kuratko, D.F., Hornsby, J.S. \& Covin, J.G., 2011, 'Operations management and corporate entrepreneurship: The moderating effect of operations control on the antecedents of corporate entrepreneurial activity in relation to innovation the antecedents of corporate entrepreneurial activity in relation to innovation
performance', Journal of Operations Management 29(1), 116-127. https://doi. org/10.1016/j.jom.2010.07.005

Grant, R.M., 1991, 'The resource-based theory of competitive advantage: Implications for strategy formulation', California Management Review 33(3), 114-135. https:// doi.org/10.2307/41166664

Grawe, S.J., Chen, H. \& Daugherty, P.J., 2009, 'The relationship between strategic orientation, service innovation, and performance', International Journal of Physical Distribution \& Logistics Management 39(4), 282-300. https://doi.org/10.1108/ 09600030910962249

Grosskopf, J., Beyers, S., Van Velden, L., Roopnarain, R. \& Stonebridge, D., 2015, Growing in turbulent times - major banks analysis - South Africa, PricewaterhouseCoopers, South Africa, viewed 25 May 2016, from http://www.pwc.co.za.uplib.idm.oclc.org/ en/assets/pdf/major-banks-analysis-march-2016.pdf

Guth, W.D. \& Ginsberg, A., 1990, 'Corporate entrepreneurship', Strategic Management Journal 11, 5-15.

Hair, J.F., Black, W.C., Babin, B.J., Anderson, R.E. \& Tatham, R.L., 2010, Multivariate data analysis, 7th edn., Pearson Prentice Hall, Upper Saddle River, NJ.
Hirt, M. \& Willmott, P., 2014, 'Strategic principles for competing in the digital age', McKinsey Quarterly 5, 1-13.

Hornsby, J.S., Kuratko, D.F. \& Montagno, R.V., 1999, 'Perception of internal factors for corporate entrepreneurship: A comparison of Canadian and US managers', Entrepreneurship Theory and Practice 24(2), 9-24. https://doi.org/10.1177/104 225879902400202

Hornsby, J.S., Kuratko, D.F. \& Shaker A.Z., 2002, 'Middle managers' perception of the internal environment for corporate entrepreneurship: Assessing a measurement scale', Journal of Business Venturing 17(3), 253-273. https://doi.org/10.1016/ S0883-9026(00)00059-8

Hornsby, J.S., Kuratko, D.F., Shepherd, D.A. \& Bott, J.P., 2009, 'Managers' corporate entrepreneurial actions: Examining perception and position', Journal of Business Venturing 24(3), 236-247. https://doi.org/10.1016/j.jbusvent.2008.03.002

Jancenelle, V.E., Storrud-Barnes, S. \& Javalgi, R.R.G., 2017, 'Corporate entrepreneurship and market performance: A content analysis of earnings conference calls', Management Research Review 40(3), 352-367. https://doi.org/10.1108/MRR-01 2016-0019

Katzan, H., 2015, 'Design for service innovation', Journal of Service Science 8(1), 1-6.

Kuratko, D.F. \& Audretsch, D.B., 2013, 'Clarifying the domains of corporate entrepreneurship', The International Entrepreneurship and Management Journal 9(3), 323-335. https://doi.org/10.1007/s11365-013-0257-4

Kuratko, D.F., Hornsby, J.S. \& Covin, J.G., 2014, 'Diagnosing a firm's internal environment for corporate entrepreneurship', Business Horizons 57(1), 37-47. https://doi.org/10.1016/j.bushor.2013.08.009

Kuratko, D.F., Hornsby, J.S. \& Hayton, J., 2015, 'Corporate entrepreneurship: The innovative challenge for a new global economic reality', Small Business Economics 45(2), 245-253. https://doi.org/10.1007/s11187-015-9630-8

Kuratko, D.F., Montagno, R.V. \& Hornsby, J.S., 1990, 'Developing an intrapreneuria assessment instrument for an effective corporate entrepreneurial environment', Strategic Management Journal 11, 49-58.

Kuratko, D.F. \& Morris, M.H., 2018, 'Corporate entrepreneurship: A critical challenge for educators and researchers', Entrepreneurship Education and Pedagogy 1(1) 42-60. https://doi.org/10.1177/2515127417737291

Kuratko, D., Morris, M.H. \& Covin, J., 2011, Corporate entrepreneurship \& innovation, Cengage Learning Emea, Hampshire.

Kline, R.B., 2011, Principles and practice of structural equation modelling, Guilford Press, New York.

Legrand, C. \& LaJoie, R., 2013, 'How service innovation boosts bottom lines', Technology Innovation Management Review 3(9), 20-25. https://doi.org/ 10.22215/timreview/724

Lekmat, L. \& Chelliah, J., 2014, 'What are the antecedents to creating sustainable corporate entrepreneurship in Thailand?', Contemporary Management Research 10(3), 181-202. https://doi.org/10.7903/cmr.11741

Lumpkin, G.T. \& Dess, G.G., 1996, 'Clarifying the entrepreneurial orientation construct and linking it to performance', Academy of Management Review 21(1), 135-172. https://doi.org/10.5465/amr.1996.9602161568

Manroop, L., 2015, 'Human resource systems and competitive advantage: An ethical climate perspective', Business Ethics: A European Review 24(2), 186-204. https:// doi.org/10.1111/beer.12069

Miller, D., 1983, 'The correlates of entrepreneurship in three types of firms', Management Science 29(7), 770-791. https://doi.org/10.1287/mnsc.29.7.770

Miller, D.J., Fern, M.J. \& Cardinal, L.B., 2007, 'The use of knowledge for technological innovation within diversified firms', Academy of Management Journal 50 (2), 307-326. https://doi.org/10.5465/amj.2007.24634437

Morrar, R., 2014, 'Innovation in services: A literature review', Technology Innovation Management Review 4(4), 6-14. https://doi.org/10.22215/timreview/780

Morris, M.H. \& Paul, G.W., 1987, 'The relationship between entrepreneurship and marketing in established firms', Journal of Business Venturing 2(3), 247-259. https://doi.org/10.1016/0883-9026(87)90012-7

Ostrom, A.L., Parasuraman, A., Bowen, D.E., Patricio, L. \& Voss, C.A., 2015, 'Service research priorities in a rapidly changing context', Journal of Service Research 18(2), 127-159. https://doi.org/10.1177/1094670515576315

Phan, P.H., Wright, M., Ucbasaran, D. \& Tan. W., 2009, 'Corporate entrepreneurship: Current research and future directions', Journal of Business Venturing 24(3), 197-205. https://doi.org/10.1016/j.jbusvent.2009.01.007

Rigtering, J.P.C. \& Weitzel, U., 2013, 'Work context and employee behaviour as antecedents for intrapreneurship', International Entrepreneurship and Management antecedents for intrapreneurship', International Entrepreneurship and
Journal 9(3), 337-360. https://doi.org/10.1007/s11365-013-0258-3

Seshadri, D. \& Tripathy, A., 2006, 'Innovation through intrapreneurship: The road less travelled', Vikalpa 31(1), 17-29. https://doi.org/10.1177/0256090920060102

Sharma, P. \& Chrisman, J.J., 1999, 'Toward a reconciliation of the definitional issues in the field of corporate entrepreneurship', Entrepreneurship Theory and Practice 23 (3), 11-27. https://doi.org/10.1177/104225879902300302

Shepherd, D.A., Covin, J.G. \& Kuratko, D.F., 2009, 'Project failure from corporate entrepreneurship: Managing the grief process', Journal of Business Venturing 24(6), 588-600. https://doi.org/10.1016/j.jbusvent.2008.01.009

Sørensen, J.B. \& Fassiotto, M.A., 2011, 'Organizations as fonts of entrepreneurship', Organization Science 22(5), 1322-1331. https://doi.org.uplib.idm.oclc.org/10.1287/ orsc.1100.0622

Steyn, R., 2017, 'The psychometric properties of a shortened corporate Entrepreneurship assessment instrument', Southern African Journal of 10.4102/sajesbm.v9i1.123 
Wang, Q., Voss, C., Zhao, X. \& Wang, Z., 2015, 'Modes of service innovation A typology', Industrial Management \& Data Systems 115(7), 1358-1382. https:// A typology', Industrial Management $\&$ D.
doi.org/10.1108/IMDS-03-2015-0067

Watanabe, K., Fukuda, K. \& Nishimura, T., 2015, 'A technology-assisted design methodology for employee-driven innovation in services', Technology Innovation Management Review 5(2), 6-14.

Witell, L., Anderson, L., Brodie, R.J., Colurcio, M., Edvardsson, B., Kristensson, P. et al., 2015, 'Exploring dualities of service innovation: Implications for service research', Journal of Services Marketing 29(6), 436-441. https://doi.org/10.1108/JSM-01 2015-0051

Yavas, U., Karatepe, O.M., Avci, T. \& Tekinkus, M., 2003, 'Antecedents and outcomes of service recovery performance: An empirical study of frontline employees in Turkish banks', International Journal of Bank Marketing 21(5), 255-265. https:// doi.org/10.1108/02652320310488439
Yunis, M., Tarhini, A. \& Kassar, A., 2018, 'The role of ICT and innovation in enhancing organizational performance: The catalysing effect of corporate entrepreneurship', organizational performance: The catalysing effect of corporate entrepreneurship,
Journal of Business Research 88, 344-356. https://doi.org/10.1016/j.jbusres.2017. 12.030

Zahra, S.A., 1993, 'Environment, corporate entrepreneurship, and financial performance: A taxonomic approach', Journal of Business Venturing 8(4), 319-340. https://doi. org/10.1016/0883-9026(93)90003-N

Zahra, S.A., 2015, 'Corporate entrepreneurship as knowledge creation and conversion: The role of entrepreneurial hubs', Small Business Economics 44(4), 727-735. https://doi.org/10.1007/s11187-015-9650-4

Zahra, S.A. \& Covin, J.G., 1995, 'Contextual influences on the corporate entrepreneurship-performance relationship: A longitudinal analysis', Journal of Business Venturing 10(1), 43-58. https://doi.org/10.1016/0883-9026(94) 00004-E 